\title{
In Vitro Testing of Salicylanilide Derivatives Against Some Fungal and Bacterial Strains
}

\author{
IOANA MARIA CARMEN IENASCU1,2, DIANA OBISTIOIU³, IULIANA MARIA POPESCU4, MARIANA NELA STEFANUT ${ }^{1}$, \\ OSSER GYONGYI ${ }^{2}$, CLAUDIA JURCA ${ }^{5}$, GABRIELA CIAVOI ${ }^{5}$, EDWIN SEVER BECHIR ${ }^{6 *}$, FARAH BECHIR ${ }^{6}$, ADINA CATA ${ }^{1}$ \\ ${ }^{1}$ National Institute of Research and Development for Electrochemistry and Condensed Matter, 144 Dr. A. P. Podeanu, 300569, \\ Timiooara, Romania \\ ${ }^{2}$ Vasile Goldis Western University of Arad, Faculty of Pharmacy, Department of Pharmaceutical Sciences, 86 Liviu Rebreanu, \\ 310045, Arad, Romania \\ ${ }^{3}$ Banat's Agricultural Science University, Faculty of Agriculture, Interdisciplinary Research Platform, 119 Calea Aradului, 300645, \\ Timiooara, Romania \\ ${ }^{4}$ Banat's Agricultural Science University, Faculty of Agriculture, Department of Chemistry and Biochemistry, 119 Calea Aradului, \\ 300645, Timionoara, Romania \\ ${ }^{5}$ University of Oradea, Faculty of Medicine and Pharmacy, 10 P-ta 1 Decembrie, 410073 Oradea \\ ${ }^{6}$ Faculty of Dental Medicine, University of Medicine, Pharmacy, Sciences and Technology of Targu Mures, 38 Gheorghe Marinescu \\ Str., 540142 Targu Mures, Romania
}

In the dental office, disinfection and sterilization are a matter of utmost importance for both the physician, the medical staff and the patient. Twelve N-(2-bromo-phenyl)-2-hydroxy-benzamide and N-(4-bromo-phenyl)2-hydroxy-benzamide derivatives were synthesized and tested for antimicrobial activity against 6 bacterial and 2 fungal strains using the Disk diffusion method for susceptibility testing. The obtained results indicated that the N-(2-bromo-phenyl)-2-hydroxy-benzamide derivatives were more active against the tested microbes, inhibition zones of 6-12 $\mathrm{mm}$ being obtained, although the most effective compound against S. pyogenes proved to be $\mathrm{N}$-(4-bromo-phenyl)-2-hydroxy-benzamide (14 mm inhibition zone). The tested compounds presented no effect against S. aureus, S. flexneri, S. typhimurium and C. parapsilopsis at the tested concentration.

Key words: N-(2-bromo-phenyl)-2-hydroxy-benzamide derivatives, N-(4-bromo-phenyl)-2-hydroxybenzamide derivatives, antibacterial effect, antifungal effect, disk diffusion method

In the last decades, a major intensification in the prevalence of resistance to antibacterial and antifungal agents has been observed. Antibiotic resistance occurs when a drug fails the capacity to inhibit bacterial growth efficiently. Bacteria become resistant and continue to proliferate in the presence of therapeutic concentration of the antibiotics. Prescription of broad spectrum antibiotics in hospitals to treat nosocomial infections increases antibiotic resistance [1].

The implications of the appearance of resistance to current antimicrobial agents would be the following: morbidity, mortality and high health care costs both in hospitals and in the community. Therefore, the researchers have been focused on a better understanding of the mechanisms of antimicrobial resistance, developed methods to detect resistance, new antimicrobial agents for such resistant microorganisms infections treatment, and approaches to prevent the occurrence and spread of resistance in the first place [2]. So, the development of effective and non-toxic antimicrobial agents is still a vital issue due to the increase of multi-resistant bacterial strains [3-7]. The most affected patients are those with compromised immune systems or with other associated diseases [8-14].

2-Hydroxybenzamide derivatives are a class of compounds with a large spectrum of biological activity, from which, 2-hydroxybenzanilides, as well as 0 substituted 2-hydroxybenzanilides proved to be potent antimicrobial agents $[15,16]$. Among the currently used antibacterial agents, nitrofurazone, furazolidone and nitrofurantoin are known to contain hydrazide-hydrazone moiety [17-20]. Due to this fact, hydrazide-hydrazone derivatives represent a good source to develop new antibacterial agents.

Development of new compounds by attaching 2hydroxybenzamides to another halogen-substituted aromatic nucleus conducted to the enhancement of the antibacterial, antiviral, anti-inflammatory and analgesic effects of these compounds. Salicylamide-O-acetic hydrazide and hydrazones displayed antiinflammatoryand analgesic effect superior to salicylamide and, at the same time, inferior ulcerogenic effect [21,22].

Novel 2-hydroxy-benzamide derivatives, esters, hydrazide and hydrazones were designed [23-27] and investigated for their biological activity $[28,29]$ in our laboratory. Antimicrobial activity of salicylanilide derivatives, esters, hydrazides and hydrazones, was evaluated in vitro against some bacteria and fungi. The minimum inhibitory concentrations obtained for esters were generally comparable to those for salicylanilide, but the hydrazides and hydrazones proved to possess superior antibacterial and antifungical effect compared to the control substance [29].

The aim of this work was to synthetize some novel 2hydroxy-benzamide derivatives and to evaluate their biological activity. The relationship between the antimicrobial activity and the structure of these synthesized compounds was also established.

\section{Experimental part}

Chemicals and strains

The reagents used for the synthesis are: 2-bromoaniline, 4-bromoaniline, phosphorus trichloride (Acros Organics, for synthesis); salicylic acid, ethyl chloroacetate, methyl 
chloroacetate (Sigma-Aldrich, for synthesis); hydrazine monohydrate, 4-dimethylaminobenzaldehyde, 5bromosalicylaldehyde (Merck, for synthesis). Solvents, chlorobenzene (Scharlau, analytical purity), absolute ethanol, dimethylformamide, 2-butanone (Merck, analytical purity), were used as supplied.

For microbiological tests, Petri plates were used, containing microcomprimates (comercial dishes with Gentamicin (10 mg-RefE110712, BioMaxima, Polonia) and Nystatin (100 mg-Re SD 025, Himedia, India). Sabouraud Dextrose Agar (Oxoid, CM0041), Sheep Blood Agar Base and Brain Heart Infusion Agar (Oxoid, CM1136) were used as culture media. Bacterial strains, S. aureus (ATCC 25923), E. coli (ATCC 25922), P. aeruginosa (ATCC 27853), S. pyogenes (ATCC 19615), S. flexneri (ATCC 12022), S. typhimurium (ATCC 14028) and fungal strains, C. albicans (ATCC 10231), C. parapsilopsis (ATCC 22019) were used.

\section{Conventional heating synthesis}

Anilide - To a mixture of salicylic acid, 2-bromoaniline and phosphorus trichloride 1:1:0.3, chlorobenzene was added. The mixture was stirred and heated to reflux for 5 h. After being cooled at room temperature, the obtained, crude product owas filtered off, washed three times successively with hot water and then three times successively with $10 \%$ sodium carbonate solution. The solid product was then filtered off, dried and recrystallized from dimethylformamide.

Ethyl/Methyl esters were added dropwise to a mixture of appropriate salicylamide and anhydrous $\mathrm{K}_{2} \mathrm{CO}_{3}$, refluxed in 2-butanone, ethyl/methylchloro-acetate. The Optimum molar ratio was amide:ester: $\mathrm{K}_{2} \mathrm{CO}_{3}=1: 1: 1$. The mixture was stirred and heated to reflux for $5 \mathrm{~h}$. After cooling at room temperature, the mixture was poured into water and shaken intensively. The organic phase was dried over $\mathrm{MgSO}_{4}$. After filtration and evaporation of solvent in vacuum, the esters were obtained in crystalline form and were recrystallized from absolute ethanol.

Hydrazide - A mixture of ethyl ester and hydrazine hydrate 1:1 was refluxed in ethanol for $3 \mathrm{~h}$. The reaction mixture was cooled, the separated solid filtered off, then subjected to recrystallization from absolute ethanol.

Hydrazones - were added to a solution of hydrazide in ethanol, the appropriate benzaldehyde was (1:1). The reaction mixture was refluxed for $5 \mathrm{~h}$. The solid obtained after cooling was filtered off, washed with water and recrystallized from dimethylformamide.

\section{Antimicrobial activity evaluation}

Antimicrobial activity of the 2-hydroxy-benzamide derivatives was tested against 6 bacterial strains, and 2 fungal strains, using the Disk diffusion method for susceptibility testing, according to the Standard Rules for Antimicrobial Susceptibility Testing using Impregnated Disks [30,31]. In vitro testing was performed in plates, containing microcomprimates with Nystatin for the antifungal activity and Gentamicin for the antimicrobial activity as positives controls, alongside blank filter papers impregnated with DMSO as negatives controls and filter papers impregnated with $10 \mu \mathrm{L}$ of $20 \mathrm{~g} / \mathrm{L}$ stock solution of each compound. A $10^{-2}$ dilution of the fresh Candida cultures and a $10^{-2}$ fresh bacteria culture was used to perform the assay, an inoculum equivalent to a 0.5 McFarland standard. The Petri plates so seeded and the respective specimens containing the tested compounds were incubated at $30^{\circ} \mathrm{C}$ for Candida species and $37^{\circ} \mathrm{C}$ in case of the bacterial strains, for 24-48 $\mathrm{h}$. Tests were performed in triplicate. Finally, the interpretation of the result, the ratio of the antimycotic and antibacterial effect of the tested compounds, was achieved by measuring the diameter of the analyzed culture inhibition zones (including the diameter of the disc $-5 \mathrm{~mm}$ ) in millimeters. The results are presented as the average of two determinations and a percentage representation of the efficacy of the compounds in relation to the effectiveness of the positive control.

\section{Results and discussions}

Twelve N-(2-bromo-phenyl)-2-hydroxy-benzamide and $\mathrm{N}$-(4-bromo-phenyl)-2-hydroxy-benzamide derivatives were synthesized, except anilides, the rest of the compounds were synthesized by our team, probably for the first time, were obtained in good yields, between 72 $92 \%$. The synthesis pathway is presented in figure 1 . The compounds were characterized using modern analytical methods, IR, NMR, elemental analysis, some of the data has already been published [28]. The synthesized compounds, yields and melting points are presented in table 1.

Table 2 presents the diameters of inhibition in $\mathrm{mm}$ and the compound efficacy expressed in percentages. The results of the microbiological tests indicated that the N-(2bromo-phenyl)-2-hydroxy-benzamide derivatives were more active against the tested microbes compared to $\mathrm{N}$ (4-bromo-phenyl)-2-hydroxy-benzamide derivatives, inhibition zones of 6-12 $\mathrm{mm}$ being obtained.

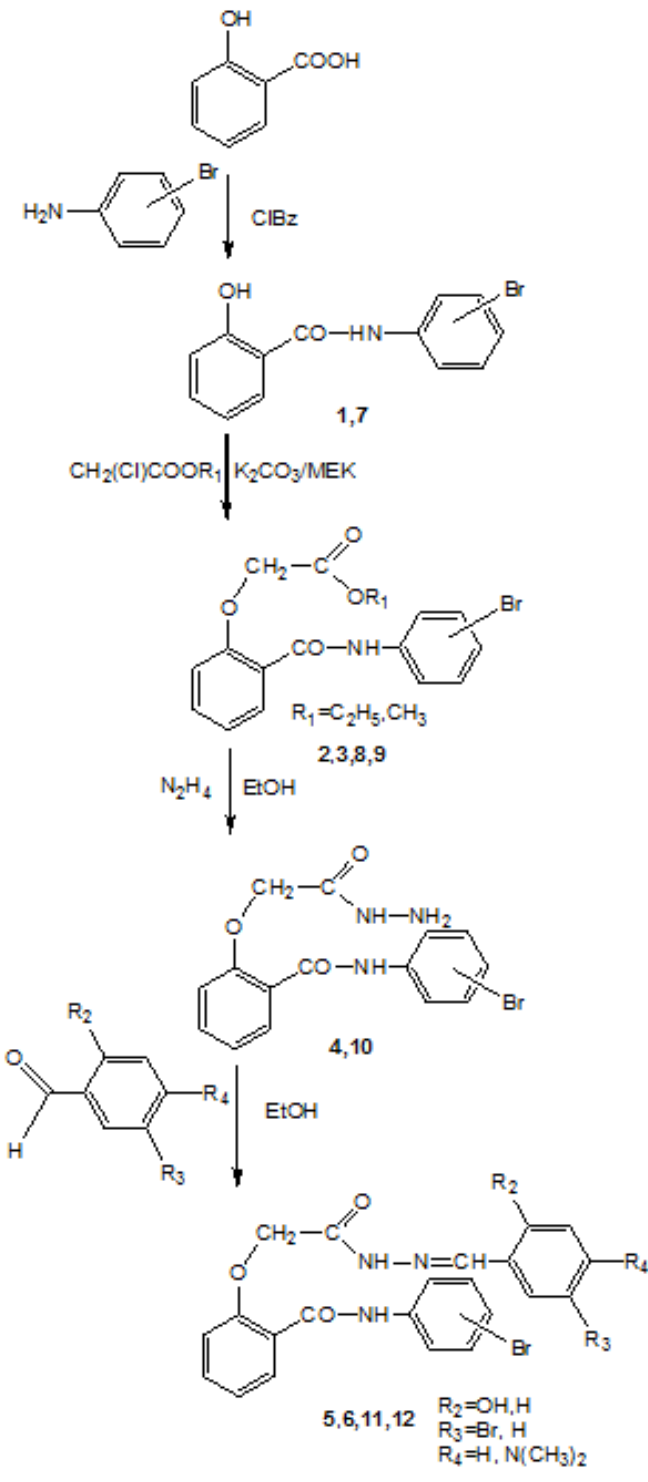

Fig. 1. 2-Hydroxy-benzamide derivatives synthesis 


\begin{tabular}{|c|c|c|c|c|c|}
\hline No. & Compound name & $\begin{array}{c}\text { Molecular } \\
\text { formula / weight }\end{array}$ & Yield (\%) & $\begin{array}{l}\text { Melting point } \\
\left({ }^{\circ} \mathrm{C}\right)\end{array}$ & \\
\hline 1. & N-(2-bromo-phenyl)-2-hydroxy-benzamide & $\begin{array}{c}\mathrm{C}_{13} \mathrm{H}_{10} \mathrm{BrNO}_{2} \\
292.13\end{array}$ & 72 & $158-161$ & \\
\hline 2. & $\begin{array}{l}\text { [2-(2-bromo-phenylcarbamoyl)-phenoxy]- } \\
\text { acetic acid ethyl ester }\end{array}$ & $\begin{array}{c}\mathrm{C}_{17} \mathrm{H}_{16} \mathrm{BrNO}_{4} \\
378.22\end{array}$ & 81 & $87-88$ & \\
\hline 3. & $\begin{array}{l}\text { [2-(2-bromo-phenylcarbamoyl)-phenoxy]- } \\
\text { acetic acid methyl ester }\end{array}$ & $\begin{array}{c}\mathrm{C}_{16} \mathrm{H}_{14} \mathrm{BrNO}_{4} \\
364.19\end{array}$ & 80 & $119-120$ & \\
\hline 4. & $\begin{array}{l}\mathrm{N} \text {-(2-bromo-phenyl)-2- } \\
\text { hydrazinocarbonylmethoxy-benzamide }\end{array}$ & $\begin{array}{c}\mathrm{C}_{15} \mathrm{H}_{14} \mathrm{BrN}_{3} \mathrm{O}_{3} \\
364.19\end{array}$ & 87 & $156-157$ & \\
\hline 5. & $\begin{array}{l}\text { 2-(5-bromo-2-hydroxy-benzylidene- } \\
\text { hydrazinocarbonylmethoxy)-N-(2-bromo- } \\
\text { phenyl)-benzamide }\end{array}$ & $\begin{array}{c}\mathrm{C}_{22} \mathrm{H}_{17} \mathrm{Br}_{2} \mathrm{~N}_{3} \mathrm{O}_{4} \\
547.20\end{array}$ & 85 & $272-273$ & Tabel 1 \\
\hline 6. & $\begin{array}{l}\mathrm{N} \text {-(2-bromo-phenyl)-2-(4-dimethylamino- } \\
\text { benzylidene-hydrazinocarbonylmethoxy)- } \\
\text { benzamide }\end{array}$ & $\begin{array}{c}\mathrm{C}_{24} \mathrm{H}_{23} \mathrm{BrN}_{4} \mathrm{O}_{3} \\
495.37\end{array}$ & 90 & $220-221$ & $\begin{array}{c}\text { THE SYNTHESIZED COMPOUNDS } \\
\text { CHARACTERISTICS }\end{array}$ \\
\hline 7. & N-(4-bromo-phenyl)-2-hydroxy-benzamide & $\begin{array}{c}\mathrm{C}_{13} \mathrm{H}_{10} \mathrm{BrNO}_{2} \\
292.13\end{array}$ & 75 & $169-172$ & \\
\hline 8. & $\begin{array}{l}\text { [2-(4-bromo-phenylcarbamoyl)-phenoxy]- } \\
\text { acetic acid ethyl ester }\end{array}$ & $\begin{array}{c}\mathrm{C}_{17} \mathrm{H}_{16} \mathrm{BrNO}_{4} \\
378.22\end{array}$ & 84 & $168-170$ & \\
\hline 9. & $\begin{array}{l}\text { [2-(4-bromo-phenylcarbamoyl)-phenoxy]- } \\
\text { acetic acid methyl ester }\end{array}$ & $\begin{array}{c}\mathrm{C}_{16} \mathrm{H}_{14} \mathrm{BrNO}_{4} \\
364.19\end{array}$ & 81 & $158-160$ & \\
\hline 10. & $\begin{array}{l}\mathrm{N} \text {-(4-bromo-phenyl)-2- } \\
\text { hydrazinocarbonylmethoxy-benzamide }\end{array}$ & $\begin{array}{c}\mathrm{C}_{15} \mathrm{H}_{14} \mathrm{BrN}_{3} \mathrm{O}_{3} \\
364.19 \\
\end{array}$ & 88 & $187-188$ & \\
\hline II. & $\begin{array}{l}\text { 2-(5-bromo-2-hydroxy-benzylidene- } \\
\text { hydrazinocarbonylmethoxy)-N-(4-bromo- } \\
\text { phenyl)-benzamide }\end{array}$ & $\begin{array}{c}\mathrm{C}_{22} \mathrm{H}_{17} \mathrm{Br}_{2} \mathrm{~N}_{3} \mathrm{O}_{4} \\
547.20\end{array}$ & 87 & $276-279$ & \\
\hline 12. & $\begin{array}{l}\mathrm{N} \text {-(4-bromo-phenyl)-2-(4-dimethylamino- } \\
\text { benzylidene-hydrazinocarbonylmethoxy)- } \\
\text { benzamide }\end{array}$ & $\begin{array}{c}\mathrm{C}_{24} \mathrm{H}_{23} \mathrm{BrN}_{4} \mathrm{O}_{3} \\
495.37\end{array}$ & 92 & $271-274$ & \\
\hline
\end{tabular}

Tabel 2

ANTIMICROBIAL ACTIVITY OF THE TESTED COMPOUNDS

\begin{tabular}{|c|c|c|c|c|c|c|c|c|}
\hline \multirow{2}{*}{$\begin{array}{c}\text { Tested } \\
\text { compunds }\end{array}$} & \multicolumn{8}{|c|}{ Diameter of inhibition (mm)/Compound efficacy (\%) } \\
\hline & S. a. & E.c. & P. a. & S.f. & S.p. & S.t. & C.p. & C.a \\
\hline l. & - & - & $6 / 40$ & - & $8 / 38$ & - & - & $7 / 35.9$ \\
\hline 2. & - & $7 / 50$ & - & - & $12 / 57.1$ & - & - & $7 / 35.9$ \\
\hline 3. & - & - & - & - & - & - & - & - \\
\hline 4. & - & $7.5 / 57.7$ & $7 / 46.7$ & - & $10.5 / 50$ & - & - & $6 / 30.8$ \\
\hline 5. & - & - & - & - & - & - & - & - \\
\hline 6. & - & - & - & - & - & - & - & $6 / 30.8$ \\
\hline 7. & - & - & $6 / 40$ & - & $14 / 66.7$ & - & - & - \\
\hline 8. & - & - & - & - & - & - & - & - \\
\hline 9. & - & - & - & - & - & - & - & - \\
\hline 10. & - & - & - & - & - & - & - & - \\
\hline 11. & - & - & - & - & - & - & - & - \\
\hline 12. & - & - & - & - & - & - & - & - \\
\hline Gentamicin & 14 & 13 & 15 & 13 & 21 & 15 & - & - \\
\hline Nystatin & - & & - & - & - & - & 16 & 19.5 \\
\hline DMSO & - & - & - & - & - & - & - & - \\
\hline
\end{tabular}

Abreviations: S. a. -Staphylococcus aureus; E. c. -Escherichia coli; P. a. -Pseudomonas aeruginosa;

S. f. -Shighella flexneri; S. p. -Streptococcus pyogenes; S. t. -Salmonella typhimurium;

C. p. -Candida parapsilopsis; C. a. -Candida albicans.

The most susceptible microorganisms to the action of the N-(2-bromo-phenyl)-2-hydroxy-benzamide derivatives are Candida albicans and Streptococcus pyogenes. Anilide , ethyl ester and hydrazide inhibited both microbes, moreover, $C$. albicans is also inhibited by hydrazone. The most active compound against Escherichia coli and Pseudomonas aeruginosa is hydrazide which exhibited a percentage of efficacy in relation to the effectiveness of Gentamicin of $57.7 \%$ and 46.7 , respectively. The highest efficacy (57.1\%) against Streptococcus pyogenes was exhibited by ethyl ester, and in case of Candida albicans, the most active compounds were anilide and ethyl ester (36.9\%).

Among N-(4-bromo-phenyl)-2-hydroxy-benzamide derivatives, N-(4-bromo-phenyl)-2-hydroxy-benzamide itself is the only one which exhibited antimicrobial activity. This compound is active only against Pseudomonas aeruginosa and Streptococcus pyogenes, with a percentage of efficacy in relation to the effectiveness of Gentamicin as positive control of 40 and $66.7 \%$, respectively, being the most effective compound ( $14 \mathrm{~mm}$ inhibition zone). However, anilide presented no effect againstfungal strains. So, the 4-substitution of aniline ring with bromine conducted to zero efficiency in terms of antifungal activity. Moreover, the substitution of phenolic hydroxyl, apparently, brings also no benefit.

The tested compounds presented no effect against $S$. aureus, S. flexneri, S. typhimurium and C. parapsilopsis at the tested concentration. $C$. albicansand S. pyogenes were very susceptible to the action of the $\mathrm{N}$-(2-bromo-phenyl)2-hydroxy-benzamide derivatives. The most active compound against $E$. coli and P. aeruginosa is hydrazide . Anilide exhibited the highest efficacy against Streptococcus pyogenes. The most potent compounds 
against Candida albicans were anilide and ethyl ester. The low efficiency of some of the tested compounds may be due to the low solubility of the compounds which act like a barrier against diffusion in the culture medium or due to the tested concentration. Thus, filter papers were impregnated with $10 \mu \mathrm{L}$ of $20 \mathrm{~g} / \mathrm{L}$ stock solution of compounds, meaning that the tested concentrations were 50 folds lower than gentamicin and 500 folds lower than nystatin.

Interactions between oral microbes and dental materials may also occur, although today not very numerous information are available regarding this possibility [32]. Under current circumstances, the issue of safety in terms of sterilization and disinfection in the dental office is of utmost importance, wherefore the study of substances used in disinfection and sterilization should be a constant concern for the specialists in the field.

\section{Conclusions}

Twelve N-(2-bromo-phenyl)-2-hydroxy-benzamide derivatives and N-(4-bromo-phenyl)-2-hydroxy-benzamide derivatives, anilides, esters, hydrazides and hydrazones, were obtained in higher yields and purity using conventional heating synthesis. Except anilides, the rest of compounds are new. The antimicrobial activity of the compounds was assessed against 6 bacterial and 2 fungal strains using the disk diffusion method. The N-(2-bromo-phenyl)-2-hydroxybenzamide derivatives were more active against the tested microorganisms, inhibition zones of $6-12 \mathrm{~mm}$ being obtained.

Among N-(4-bromo-phenyl)-2-hydroxy-benzamide derivatives, onlyanilide exhibited antimicrobial effect, being active against Pseudomonas aeruginosa and Streptococcus pyogenes; no effect against fungal strains was obtained. In case of N-(4-bromo-phenyl)-2-hydroxybenzamide derivatives, the substitution of phenolic hydroxyl, apparently, is not favorable for antimicrobial effect, but this may also be due to the low solubility/ diffusion of the compounds in the culture medium or due to the tested concentration. These results demonstrated once more the great potential of 2-hydroxy-benzamide derivatives as antimicrobial agents.

\section{References}

1.ZAMAN, S. B., HUSSAIN, M. A., NYE, R., MEHTA, V., MAMUN, K. T., HOSSAIN, N. Cureus., 9, no. 6, 2017, el403.

2.DIACONU, C.C., DRAGOI, C.M., BRATU, O.G., NEAGU, T.P., STOIAN, A.P., COBELSCHI, P.C., NICOLAE, A.C., IANCU, M.A., HAINAROSIE, R., STANESCU, A.M.A., SOCEA, B., Farmacia, 66, no. 3, p. 408.

3.MOELLERING, Jr. R. C., Int. J. Antimicrob. Agents, 37, 2011, p. 2. 4.PALLAG, A., JURCA, T., SIRBU, V., HONIGES, A., JURCA, C., Rev. Chim. (Bucharest), 69, no. 2, 2018, p. 445.

5.PALLAG, A., FILIP, G.A., OLTEANU, D., CLICHICI, S., BALDEA, I., JURCA, T., MICLE, O., VICAS, L., MARIAN, E., SORITAU, O., CENARIU, M., MURESAN, M., Oxid. Med. Cell. Longev., 2018, ID 3060525, 14 pages, https://doi.org/10.1155/2018/3060525

6.SPINU, D., BRATU, O., MARCU, D., MISCHIANU, D., HUICA, R., SURCEL, M., MUNTEANU, A., SOCEA, B., BODEAN, O., URSACIUC C., Rev. Chim. (Bucharest), 69, no. 3, 2018, p. 645.
7.MEHEDINTU, C., ANTONOVICI, M., BRINDUSE, L., BRATILA, E., STANCULESCU, R., BERCEANU, C., BRATU, O., PITURU, S., ONOFRIESCU, M., MATASARIU, D.R., Rev. Chim. (Bucharest), 69, no. 3, 2018, p. 581.

8.COATES, A., HU, Y., BAX, R., PAGE, C., Nat. Rev. Drug Discov., 1, 2002, p. 895.

9.TIT, D.M., PALLAG, A., IOVAN, C., FURAU, G., FURAU, C., BUNGAU, S., Iran. J. Public Health, 46, no.11, 2017, p. 1128.

10.PALLAG, A., ROSCA, E., TIT, D.M., MUTIU, G., BUNGAU, S. G., POP, O. L.,Rom. J. Morphol. Embriol., 56, no. 3, 2015, p. 1103.

11.MRAZ, C., MURESAN, M., MICLE, O., VICAS, L., PALLAG, A., COLTAU, M., PUSCAS, I., Farmacia, 60, no. 2, 2012, p. 264.

12.FODOR, K., TIT, D.M., PASCA, B., BUSTEA, C., UIVAROSAN, D., ENDRES, L., IOVAN, C., ABDEL-DAIM, M., BUNGAU, S., Oxid. Med. Cell. Longev, 2018, 2018, ID 4147320, 10 pages. https://doi.org/10.1155/ 2018/4147320

13.TIT, D.M., BUNGAU,S., IOVAN,C., NISTOR CSEPPENTO,D.C., ENDRES, L., SAVA, C., SABAU, A.M., FURAU, G., FURAU, C., JCM, 7, no. 10, 2018, p. 297. doi: 10.3390/jcm7100297

14.ABDEL-DAIM, M.M., ZAKHARY, N.I., ALEYA, L., BUNGAU, S. G., BOHARA, R.A., SIDDIQI, N.J ., Oxid. Med. Cell. Longev., 2018, 2018, ID 2098123, 2 pages. https://doi:10.1155/2018/2098123

15.MATYK, J., WAISSER, K., DRAZKOVA, K., KUNES, J., KLIMENSOVA, V., PALAT, K.J R., KAUSTOVA, J., Farmaco., 60, no. 5, 2005, p. 399.

16.WAISSER, K., MATYK, J., DIVISOVA, H., HUSAKOVA, P., KUNES, J., KLIMENSOVA, V., KAUSTOVA, J., MOLLMANN, U., DAHSE, H.M., MIKO, M., Arch Pharm., 339, no. 11, 2006, p. 616.

17.MCCALLA, D.R., REUVERS, A., KAISER, C., J . Bacteriol., 104, 1970, p. 1126.

18.CHATTERJEE, S.N., GHOSH, S., Indian J. Biochem. Biophys., 16, no. 3, 1979, p. 125.

19.ALI, B.H., Vet. Res. Commun., 6, 1983, p. 1.

20.MUNOZ-DAVILA, M.J., Antibiotics, 3, 2014, p. 39.

21.FAHMY, H.H., EL-ERAKY, W., Arch. Pharm. Res., 24, no. 3, 2001, p. 171.

22.FAHMY, H.H., SOLIMAN, G.A., Arch. Pharm. Res., 24, no. 3, 2001, p. 180.

23.IENASCU, I.M.C., LUPEA, A.X., POPESCU, I.M., PADURE, M.A., ZAMFIR, A.D., J. Serb. Chem. Soc., 74, no. 8-9, 2009, p. 847.

24LUPEA, A.X., POPESCU, I., TARABASANU, C., IENASCU, I., PADURE, M.,Rev. Roum.Chem., 51, nr. 6, 2006, p. 517

25.IENASCU, I.M.C., PADURE, M.A., LUPEA, A.X., BALCU, I., POPESCU, I.M., Rev. Chim. (Bucharest), 61, no. 4, 2010, p. 368

26.IENASCU, I.M.C., LUPEA, A.X., POPESCU, I., TOMAS, S., ZAMFIR, A.D., Rev. Chim. (Bucharest), 59, no. 1, 2008, p. 56.

27.IENASCU, I.M.C., LUPEA, A. X., POPESCU, I., MOSOARCA, C., ZAMFIR, A.D., Rev. Chim. (Bucharest), 53, no. 4, 2008, p. 273.

28.IENASCU, I.M.C., BALAES, T., PETRE, C.V., POP, R.O., CATA, A., STEFANUT, M. N., ALBU, P., POENARU, M., Rev. Chim. (Bucharest), 69, no. 7, 2018, p. 1876.

29.IENASCU, I.M.C., LUPEA, A. X., HADARUGA, D., HADARUGA, N., POPESCU, I., Rev. Chim. (Bucharest), 59, no. 2, 2008, p. 247.

30.CAVALIERI, I., STEPHEN, J., Manual of Antimicrobial Susceptibility Testing, M.B. Coyle (Coord. Editor), American Society for Microbiology, 2005, p. 39.

31.SIRBU, V., PALLAG, A., HOENIGES, A., COJ OCARU S.I., Rev. Chim. (Bucharest), 68, no.2, 2017, p.390.

32.BECHIR, A., PACURAR, M., BECHIR, E.S., COMANEANU, R.M., CHIBELEAN CIRES, M., MARIS, M., BARBU, H.B., Mat. Plast., 51, no. 1,2014 , p. 54-61

Manuscript received: $21 \cdot 10.2018$ 